\title{
NEW SPECIES OF NORTH AMERICAN DOLICHOPODIDA
}

\author{
By M. C. Van Duzee, \\ Buffalo, N. Y.
}

Hydrophorus maculipennis new species.

Male: Length $3.5 \mathrm{~mm}$; of wing $4 \mathrm{~mm}$. Face wide, but little narrowed above, upper portion green with only a little pollen; lower part opaque with yellow pollen. Palpi black with pale hairs. Front opaque with brown pollen. Antennæ black, third joint small, nearly round; arista whitish at tip. Cheeks very narrow. Beard yellow, not very long or abundant, the black orbital cilia decend to the middle of the eye.

Dorsum of thorax shining blackish with thin brown pollen, which is more abundant on the sides and ends abruptly a little below the pleural suture; pleuræ bare, more greenish, the pollen white, contrasting strongly with that above; acrostichal and dorsocentral bristles very short, hair-like; propleuræ with one black bristle and some small, pale hairs above each fore coxa; scutellum with two pair of marginal bristles. Abdomen green with brown pollen above, white on the sides, the line between being sharply defined; hairs of the abdomen very minute, black, white only on lower edges of the sides. Hypopygium concealed, with a pair of quite large, black lamellæ projecting backward, they have a few pale hairs on upper edge.

Fore coxæ green, nearly bare, but with a few minute white hairs and several short, black, hair-like bristles on outer edge and one at tip; middle and hind coxæ black with white pollen. Femora and tibiæ green, their hair mostly black. Fore femora thickened, tapering to the tip, with one row of ten black spines extending nearly their whole length on lower anterior edge, lower surface with pale hairs. Fore tibiæ with the usual row of spines on lower surface extending their whole length. Middle and hind femora with several bristles below, their tibiæ with more numerous bristles below, the former with six, the latter with three 
bristles on anterior surface. Tarsi black with white pulvilli; fifth joint of middle and hind tarsi very slightly widened. Joints of fore tarsi as 29-14-11-7-10; of middle ones as 33-22-17-10-12; those of posterior pair as 35-23-17-12-16. Calypters yellow with white cilia. Halteres blackish with the stem partly yellow.

Wings grayish, tinged with brown in front of second vein; a dark brown, nearly round spot on the cross-vein and on the middle of last section of fourth vein, this section being nearly straight; veins wholly black, not at all yellow at root of wing.

Described from one male taken at Newport, Oregon, June 8, 1925, by E. C. Van Dyke.

Type in the California Academy of Sciences.

Hydrophorus nigrinervis new species.

Male: Length $3.2 \mathrm{~mm}$; of wing $4.2 \mathrm{~mm}$. Face wide below, narrowed above, wholly covered with white pollen. Palpi black with black hair. Front opaque with brown pollen. Antennæ black, short, third joint nearly round in outline; arista thick with a bristle-like tip, a little longer than the antenna. Beard scanty, white; the black orbital cilia do not reach down to the middle of the eye. One pair of postverticals. Cheeks extending narrowly below the eyes.

Thorax and abdomen bright metallic green; pleuræ and sides of abdomen dulled with white pollen; propleuræ with one black bristle on each side above fore coxæ; scutellum with two pair of bristles; hair on the dorsum of the abdomen black. Hypopygium black with white pollen, its hair white; its appendages extending downward, as long as height of hypopygium with several long, white hairs at tip.

Fore coxæ green with white pollen and hair; no black bristles at tip; middle and hind coxæ black with white pollen. Femora and tibiæ green, their hair black; fore femora thickened on basal portion, narrowed at tip, with two, closely approximated rows of spines below, one of which extends their whole length; fore tibiæ with a row of short, erect spines on whole lower edge; middle femora with a row of short bristles on lower posterior edge of apical two thirds and three small ones on lower anterior 
edge near the tip; posterior femora with a row of six small bristles on lower anterior edge of apical half and three on posterior edge near the tip; fore and middle tibiæ each with five to seven small bristles below. Tarsi black with white hair; middle and hind basitarsi with a row of minute black spines below. Joints of fore tarsi as 31-14-14-10-11; of middle pair as 51-24-20-14-13; those of posterior tarsi as 43-31-24-16-12. Calypters yellow with white cilia. Halteres yellow.

Wings grayish hyaline, without spots on the veins; veins black, not yellow at root of wing; last section of fourth vein nearly straight; third vein bent a little backward at tip.

Female: Length $3.5 \mathrm{~mm}$; of wing $5 \mathrm{~mm}$. Pollen of face more brown on upper portion, yellow on lower part, becoming white along the orbits, the pollen scarcely concealing the ground color. Fore femora with a single row of spines below in the middle for half their length. Otherwise about as in the male.

Described from two males and one female, taken at Komloops, British Columbia, July 30, by N. Criddle.

Type in the Canadian National Collection.

Hydrophorus albomaculatus new species.

Female: Length $5 \mathrm{~mm}$. of wing $6 \mathrm{~mm}$. Face wide, its sides nearly parallel, opaque with white pollen. Palpi black, their pollen and hair white. Cheeks wide, extending as far down as the tips of the palpi. Front opaque with brown pollen. Antennæ black; first joint as long as the last two taken together; third nearly square in outline; arista thick, as long as the antenna. Beard abundant, long, white; the black orbital cilia decend to apical fourth of the eye; postvertical bristles in a row of four on each side, extending to the orbital cilia.

Thorax blackish with three lines along the rows of bristles which are more gray with pollen; humeri and narrow lateral edgrs of the dorsum white pollinose; three black propleural bristles above each fore coxa and long white hairs above and below these bristles; scutellum with four pairs of marginal bristles, the outer pair small; there are several small pale hairs on the pleuræ above middle coxæ. Abdomen black, thickly covered 
with white pollen, in the type there are many dots where the ground color shows through, its hairs white and conspicuous.

Coxæ, femora, tibiæ and tarsi black with more or less white pollen. Fore coxæ with moderately long, white hair. Fore femora thickened, lower anterior surface with a stripe of numerous, quite long, irregular bristles, extending their whole length. Anterior tibiæ with quite long pale hair on the front surface; all tibiæ and tarsi with minute white hairs below, which are longer on anterior and posterior basitatsi, the latter bent and with several long, black, bristle-like hairs above. Joints of fore tarsi as 46-25-20-14-18; first two joints of middle tarsi as 78-39; joints of posterior pair as 64-43-35-26-22. Calypters, their cilia and the halteres pale yellow.

Wings dark grayish; in front of third vein, except at tip, between third and fourth veins to a short distance before the cross-vein; a roundish spot at anal angle, a spot between fourth and fifth veins before the cross-vein and a small spot between third and fourth veins near their tips whitish, these spots conspicuous without a lens; veins blackish, except sixth vein which is snow white towards its tip; last section of fourth vein somewhat arched.

Described from one female, taken at Aweme, Manitoba, July 12,1925 , by R. D. Bird.

Type in the Canadian National Collection.

Hydrophorus flavipennis new species.

Male: Length $4.5 \mathrm{~mm}$; of wing $4 \mathrm{~mm}$. Face wide, scarcely narrowed above, green with silvery white pollen, which is most conspicuous around the edge of lower portion. Palpi black with white hair. Front metallic coppery, dulled with grayish pollen. Antennæ black, third joint small, nearly round in outline; arista black with apical half yellowish white. Beard long and abundant, snow white; I can see only about five black cilia on upper orbits.

Thorax green, dorsum with a narrow brown line each side of the acrostichal bristles, and two less distinct lines on each side of these; it has a very little gray pollen; pleuræ with white hair above middle coxæ; propleuræ with long white hair above each 
fore coxa, but without a black bristle; dorsocentral bristle next to the scutellum large, the rest very small; scutellum with two pair of bristles. Abdomen coppery with the hind margins of the segments black, its hairs white, short on the dorsum, long on the sides. Hypopygium concealed, with a pair of long black appendages projecting downward with a small tip turned forward, fringed with small white hairs.

Fore coxæ dark green, their long hair and the pollen silvery white; middle and hind coxæ black. All femora and tibiæ dark green with white hair; fore femora thickened, their tips narrowed; they have eight short, blunt spines before the middle on lower surface, the first placed a considerable distance from base of femora; posterior femora with a conspicuous bend near the base, the concave side down, beyond this bend they are a little thickened. Fore tibiæ with a row of minute spines on their whole lower edge; middle tibiæ with two minute black bristles above near the base, posterior pair with several very small ones on upper surface. Tarsi black with white hair, first four joints of middle and hind tarsi with minute black spines below; fifth joint of middle tarsi slightly widened. Joints of fore tarsi as 25-18-13-9-12; of middle ones as 38-18-13-8-12; those of posterior pair as 50-25-20-12-14. Calypters and halteres yellow, the former with white cilia.

Wings with a yellowish sheen on anterior half, posterior half more gray; costa and veins bright yellow, veins on posterior half usually more brownish.

Female: Length $4.5 \mathrm{~mm}$.; of wing $5 \mathrm{~mm}$. Face and front very wide, covered with yellowish pollen, the bronze ground color showing through, except on lower portion, the face long, reaching nearly to the lower corner of the eyes; the black cilia reach down to the middle of the eye; pollen on the dorsum of the thorax more dense than in the male, fore coxæ with shorter hair; fore femora with two rows of spines below for nearly their whole length; posterior femora not bent at base; all tibiæ and middle and hind femora with a few scattering black bristles. Wings, hairs of the abdomen, legs and feet as in the male.

Described from one male and six females which I have taken, the male and two females (type and allotype) taken at 
Wainfleet, Ontario, July 20 and 26, 1924; two females at Ridgeway, Ontario, July 24, 1910; one at Buffalo, October, 18, 1910, and one female at Needles, California, February, 18, 1915.

Type in the author's collection.

Hydrophorus lividipes new species.

Male: Length $4 \mathrm{~mm}$.; of wing $5 \mathrm{~mm}$. Face wide with silvery white pollen, the blue-green ground color showing through a little on upper portion. Palpi black with abundant black hair. Front opaque with brown pollen. Antennæ black, short; third joint scarcely as long as wide. Beard rather long, yellowish; the black orbital cilia extend down nearly to the lower margin of the eye. Cheeks wide, extending lobe-like below the eyes, about as long as the palpi.

Dorsum of thorax and its pollen brown; pleuræ green with white pollen, bare, one propleural bristle on each side and several pale hairs below them; two pairs of scutellar bristles. Dorsum of abdomen brown with slight green reflections and brown pollen; its sides shining green with only a little white pollen on lower edges; hairs on first segment long and white; on the others short, black. Hypopygium and its pollen brown, its appendages small, extending downward, scarcely as long as wide, with a little point at tip extending forward, fringed with short hair.

Fore coxæ green, anterior surface with white hair and pollen and a row of about five small black bristles of equal length on outer edge of apical half; middle and hind coxæ black with white pollen. All femora and tibiæ dark blue-green with black hair, each with several small bristles below. Anterior femora thickened, narrowed towards their tips; I can see only one row of spines on lower surface, which are on the anterior edge and placed rather far apart (there may be another row), they also have pale hair on lower surface, fore tibiæ with pale hair on the sides. Tarsi black with brown pollen; first joint of middle and hind pairs with very small spines below, the latter also have pale hair on lower surface. Joints of fore tarsi as 36-17-15-12-13; of middle ones as 44-27-21-15-16; those of posterior pair as 48-30-2315-15. Pulvilli of all tarsi large, pale in color. Calypters yellow 
with reddish border and white cilia. Halteres blackish, stem yellow in the middle.

Wings grayish, strongly tinged with brown in front of third vein as far as tip of second; veins without spots; last section of fifth vein straight, third considerably bent back near the tip; veins wholly black.

Described from a single male taken at Aweme, Manitoba, April 8, 1925, by N. Criddle.

Type in the Canadian National Collection.

Hydrophorus argentifacies new species.

Male: Length $2.7 \mathrm{~mm}$.; of wing $3.5 \mathrm{~mm}$. Face wide below, narrowed above, silvery white, slightly brown just below the antennæ, in certain lights it is tinged with green because of the ground color. Palpi black with gray pollen and pale hair. Front green with brown pollen, antennæ black, short, third joint nearly round in outline. Beard yellow, the black orbital cilia decend to about the middle of the eye. Cheeks narrow, truncate below.

Dorsum of thorax and its pollen brown; pleuræ and abdomen green, dulled with white pollen, the latter with black hair, except on lower edge of the sides; propleuræ with one black bristle and several white hairs on each side above fore coxa; sides of pleuræ bare; scutellum with two pair of marginal bristles. Hypopygium black, its appendages short, rounded, about as long as wide, with only short hair on apical edge.

Fore coxæ green with yellowish hair on anterior surface, no black bristle at tip; middle and hind coxæ black with gray pollen. Femora and tibiæ green with black hair, except on anterior tibiæ. Fore femora thickened on basal portion, narrowed at tip; they have a few short spines below, apparently in a single row (cannot see them very well in the type), their tibiæ with the usual row of spines below; middle and hind femora without a bristle below, except a small one near the tip, posterior tibiæ without, middle ones with one small bristle below, tarsi dark brown; fifth joint of middle ones black and slightly widened. Joints of fore tarsi as 30-16-15-10-12; of middle ones as 43-18-15-10-8, fifth joint 5 wide; posterior tarsi with their joints as 43-24-19-11-10. Calyp- 
ters yellow with white cilia. Halteres yellow, knobs darker, but scarcely blackened.

Wings grayish, darker on anterior half; cross-vein bordered with brown a very little; last section of fourth vein straight; third vein bent backward a very little at tip.

Female: Length $3 \mathrm{~mm}$; of wing $4 \mathrm{~mm}$. Face wider, dark gray. Front opaque with brown pollen; hair on fore coxæ a little more yellowish than in the male. Fore femora with a row of four quite long bristles below and a stripe of very short spines on lower anterior surface; fifth joint of middle tarsi not widened; last section of fourth vein with a very faint cloud at its middle; halteres wholly yellow. Joints of fore tarsi as 32-17-13-9-12; of middle ones as 47-26-17-11-13, those of posterior pair as 41-3221-12. Otherwise about as in the male.

Described from one pair, taken at Treesbank, Manitoba, September 16, 1925, by N. Criddle. They are in the Canadian National Collection. 

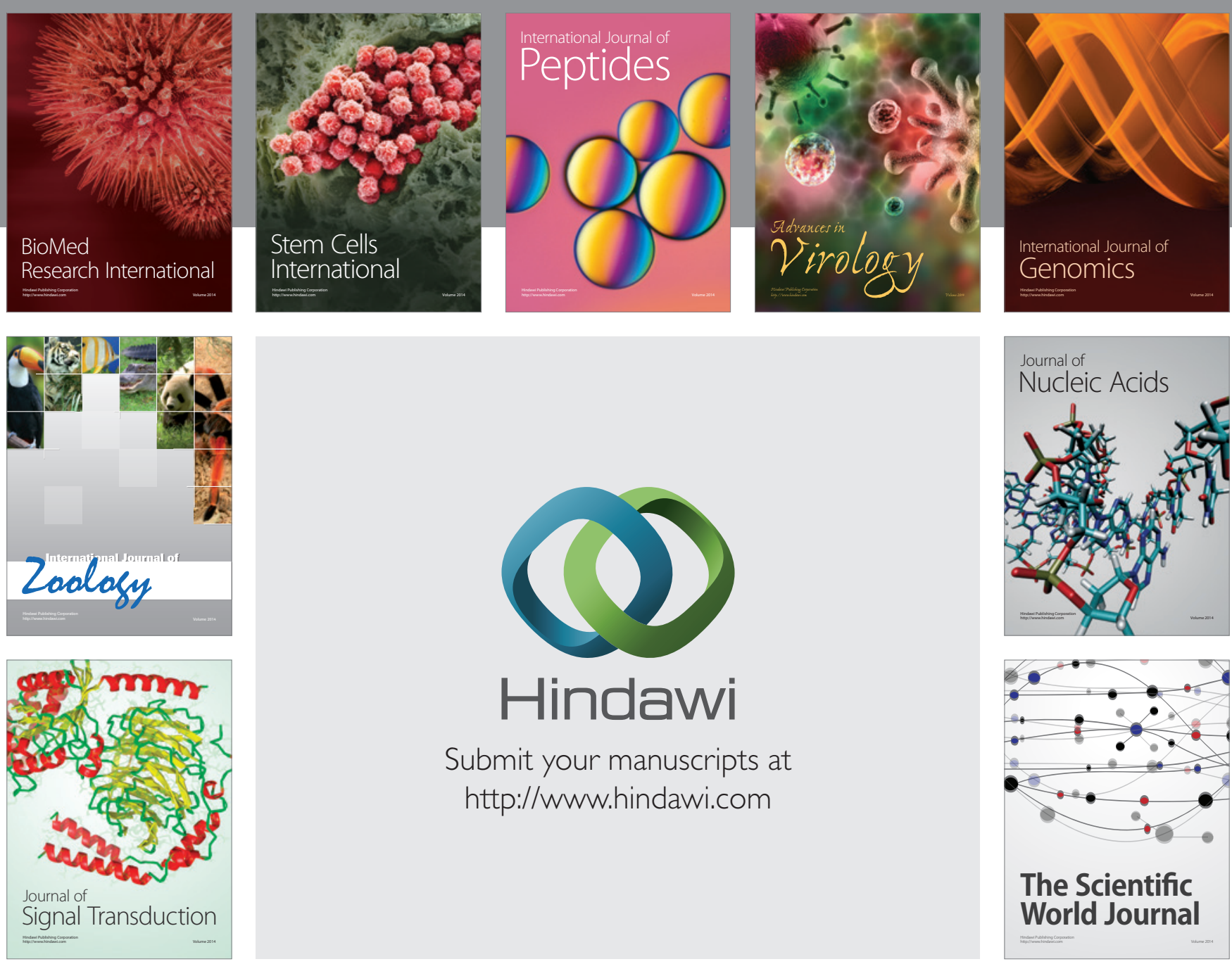

Submit your manuscripts at

http://www.hindawi.com
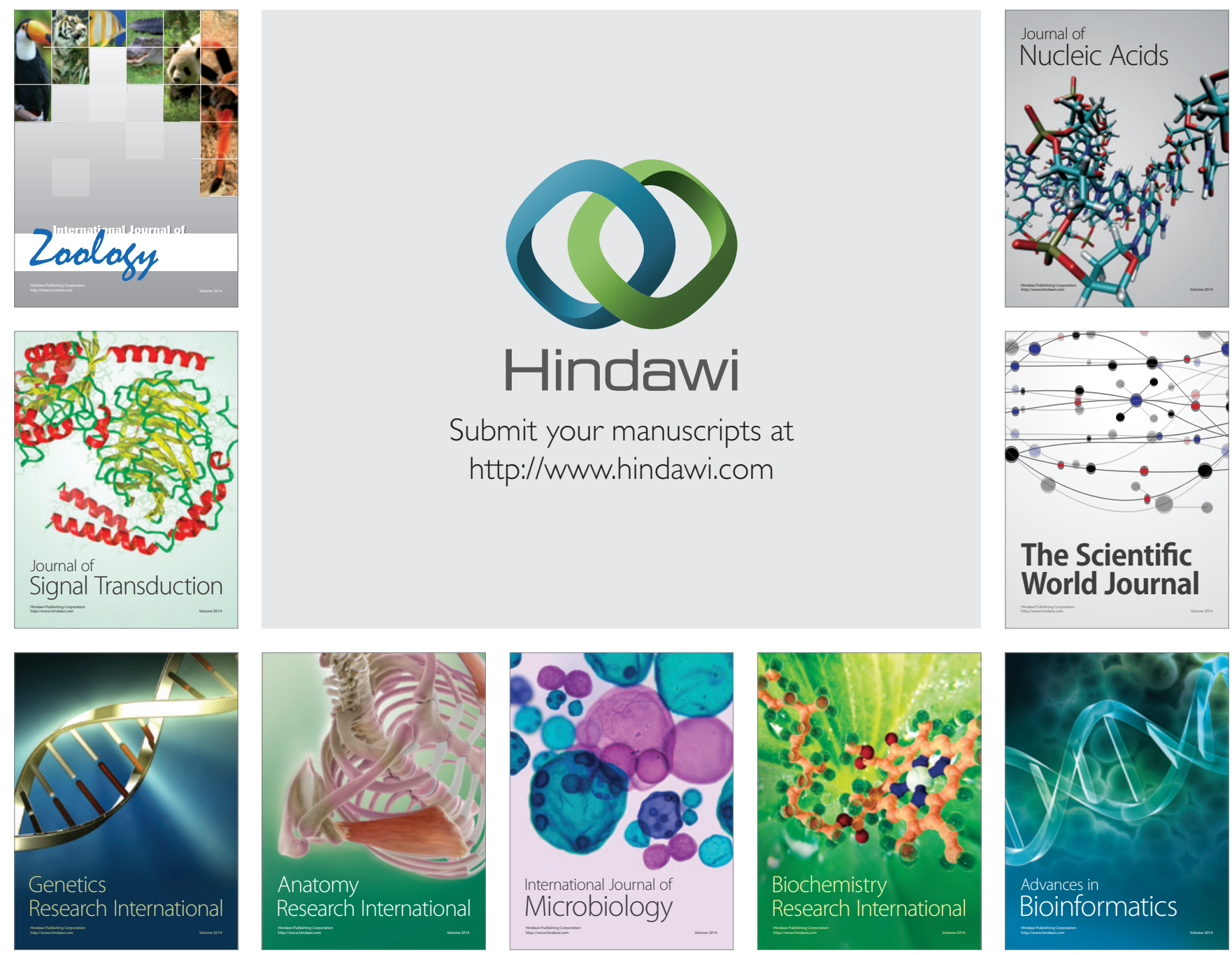

The Scientific World Journal
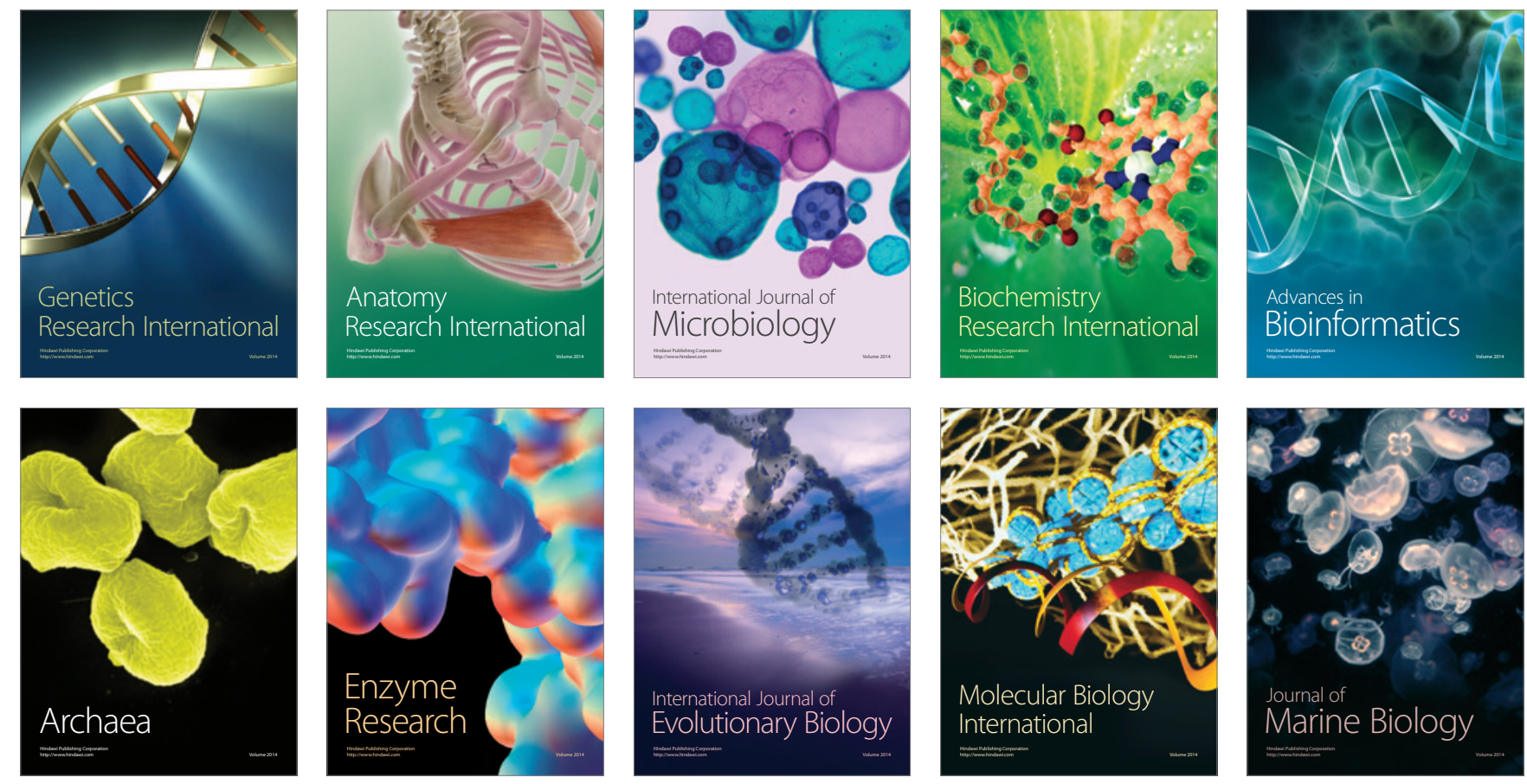